\title{
Hubungan Kondisi Lingkungan dengan Keberadaan Jentik Aedes aegypti di Daerah Endemis DBD di Kota Banjarbaru
}

\section{The Correlation between Environmental Conditions and the existence of larvae Ae. aegypti in the DHF Endemic Area in Banjarbaru City}

\author{
Norsita Agustina*, Abdullah, Edy Arianto \\ Fakultas Kesehatan Masyarakat Universitas Islam Kalimantan Muhammad Arsyad Al-Banjary \\ Banjarmasin \\ Jalan Adhyaksa Nomor 2 Kayu Tangi Banjarmasin, Kalimantan Selatan, Indonesia \\ *E_mail: norsita.agustina@gmail.com
}

Received date: 27-03-2019, Revised date: 23-09-2019, Accepted date: 11-10-2019

\begin{abstract}
ABSTRAK
Kota Banjarbaru merupakan daerah endemis Demam Berdarah Dengue (DBD), khususnya Kelurahan Guntung Manggis. Jumlah kasus DBD tahun 2018 sebanyak 10 orang dengan kematian 2 orang. Tujuan penelitian untuk menganalisis hubungan kondisi lingkungan dengan keberadaan jentik Aedes aegypti. Penelitian menggunakan studi analitik dengan pendekatan cross sectional yang dilakukan pada bulan Januari 2019. Populasi adalah semua rumah yang ada di RT 46 RW III Kota Banjarbaru sebanyak 168 rumah, sampel sebanyak 63 rumah dengan menggunakan teknik random sampling. Pengumpulan data jentik Ae. aegypti dengan metode single larva. Data kondisi lingkungan didapatkan dengan pengukuran derajat keasaman $(\mathrm{pH})$ dan pengukuran suhu air. Analisis data menggunakan uji chi-square dan uji fisher exact dengan nilai kemaknaan $(\alpha) 0,05$. Hasil penelitian menunjukkan suhu air dan jenis kontainer berhubungan dengan keberadaan jentik Ae. aegypti ( $p$-value 0,000). Sedangkan derajat keasaman $(\mathrm{pH})$ tidak berhubungan dengan keberadaan jentik Ae. aegypti (p-value 0,144).
\end{abstract}

Kata kunci: Ae. aegypti, jentik, kondisi lingkungan, endemis, demam berdarah Dengue

\begin{abstract}
Banjarbaru City is one of dengue endemic area, perticularly Guntung Manggis Village. In 2018, as many as 10 people affected by DHF with the death of 2 people. The purpose of the study was to analyze the environmental conditions related to the existence of Ae. aegypti larvae. The study uses analytic studies with cross-sectional approach conducted in January 2019. The population is all houses in RT 46 RW III Banjarbaru City as many as 168 sample houses, and 63 houses using random sampling techniques. Larva data collection was carried out with the single larva method. Data on environmental conditions were obtained by measuring the degree of acidity $(\mathrm{pH})$ and measurement of water temperature. Data analysis used chi-square test and fisher exact test with significance value $(\alpha)$ 0.05. The results showed that water temperature and type of containers were related to the presence of Ae . aegypti larvae (p-value 0.000). While the degree of acidity $(\mathrm{pH})$ is not related to the presence of Ae. aegypti larvae. (p-value 0.144).
\end{abstract}

Keywords: Ae. aegypti, larvae, environmental conditions, endemic, Dengue Hemorrhagic Fever

\section{PENDAHULUAN}

Di Indonesia, nyamuk Aedes aegypti cenderung berkembangbiak dan hidup di sekitar pemukiman rumah yaitu di tempat yang terdapat banyak penampungan air jernih dan bersih dalam bak mandi dan gentong yang menjadi sarang berkembangbiaknya. Selain itu, nyamuk hidup berdiam dan berkembang biak di genangan air bersih yang tidak kontak secara langsung dengan tanah. Vektor ini diketahui banyak bertelur di genangan air yang terdapat pada tempat penampungan air, bak mandi, sisa-sisa kaleng bekas, ban bekas, dan sebagainya. ${ }^{1}$

Vektor utama Demam Berdarah Dengue (DBD) adalah nyamuk Ae. aegypti yang berkembang biak pada tempat-tempat penampungan air berupa genangan air yang tertampung di bejana baik di dalam maupun di luar rumah. Keberadaan Ae. aegypti 
dipengaruhi oleh faktor manusia dan lingkungan. Faktor lingkungan yang terkait dengan keberadaan Ae. aegypti antara lain, jenis Tempat Penampungan Air (TPA), curah hujan, suhu udara, kelembaban udara, ketinggian tempat, pengaruh angin, keberadaan tanaman, dan variasi musim. Sedangkan faktor manusia yang terkait dengan keberadaan $A e$. aegypti yaitu, kepadatan penduduk, mobilitas penduduk, jarak antar rumah, intensitas cahaya, dan perilaku Pemberantasan Sarang Nyamuk (PSN) DBD. ${ }^{2}$ Kasus Dengue meningkat di musim penghujan dan menurun di musim kemarau. ${ }^{3}$

Penyakit DBD perlu mendapatkan perhatian yang serius karena dapat menimbulkan kematian. Berdasarkan laporan Dinas Kesehatan Kota Banjarbaru, jumlah kasus/Incidence Rate (IR) DBD di Kota Banjarbaru tahun 2017 sebesar (17,68 kasus/ 100.000 penduduk). Tahun 2018 terjadi peningkatan angka IR (52,58 kasus/100.000 penduduk) dengan Case Fatality Rate (CFR) sebesar 0,01 dan sampai bulan Juli 2019 turun menjadi 34,1 kasus/100.000 penduduk. ${ }^{4}$

Penelitian Suryaningtyas menyebutkan bahwa jumlah kasus DBD di suatu wilayah dipengaruhi oleh keberadaan jentik Ae. aegypti pada kontainer-kontainer terutama yang digunakan untuk kebutuhan manusia. Jumlah kasus DBD di beberapa wilayah dipengaruhi oleh keberadaan jentik Ae. aegypti pada kontainer-kontainer yang digunakan untuk kebutuhan manusia. Keberadaan kontainer tersebut berhubungan dengan keberadaan jentik. Hal ini disebabkan oleh keberadaan kontainer/tempat penampungan air di sekitar tempat tinggal berpotensi sebagai tempat perkembangbiakan Ae. aegypti dan memperbesar pula potensi kontak dengan manusia. $^{5}$

Terjadinya peningkatan kasus dan makin meluasnya daerah endemis DBD ini di sebabkan antara lain dengan tingginya mobilitas dan kepadatan penduduk, nyamuk penular DBD (Ae. aegypti) tersebar di seluruh pelosok tanah air dan masih di gunakannya TPA tradisional (tempayan, ban, drum, dll). ${ }^{6}$
Penelitian dari berbagai negara menunjukkan bahwa ketersediaan kontainer penampung air mempengaruhi kehidupan nyamuk di suatu daerah sehingga meningkatkan risiko peningkatan penyakit tular vektor. Sampai saat ini vaksin dan obat mulai ditemukan untuk pencegahan dan pengobatan, namun pengendalian lingkungan dengan cara pemberantasan sarang nyamuk tetap menjadi cara yang paling efektif untuk dilakukan. Selain ketersediaan kontainer, pertumbuhan nyamuk juga dapat dipengaruhi oleh kondisi lingkungan seperti suhu air, kelembapan, dan juga $\mathrm{pH}$ air. Kondisi tersebut dapat bervariasi karena perbedaan geografis, variasi musiman, atau bahkan perubahan iklim. ${ }^{7}$ Penelitian Ridha $^{8}$ menunjukan bahwa faktor lingkungan yang berhubungan dengan keberadaan jentik Ae. aegypti adalah $\mathrm{pH}$, suhu air, dan kelembaban udara, sedangkan suhu udara tidak berhubungan dengan keberadaan jentik nyamuk Ae. aegypti.

Keberadaan kontainer di sekitar tempat tinggal dan upaya masyarakat dalam mengendalikan populasi Ae. aegypti menentukan keberadaan jentik di sekitar tempat tinggal manusia. Keberadaan jentik $A e$. aegypti di Jakarta Barat di pengaruhi oleh tingkat pendidikan keluarga, jenis, letak, dan jumlah kontainer yang digunakan per rumah. Faktor lain yaitu pemilihan penggunaan jenis formulasi serta frekuensi penggunaan insektisida rumah tangga di Jakarta Barat tidak berhubungan dengan keberadaan jentik $A e$. aegypti. $^{9} \quad$ Semakin meningkatnya angka kejadian DBD di RT 46 RW III Kelurahan Guntung Manggis Kota Banjarbaru tidak lepas dari tempat perkembangbiakan jentik $A e$. aegypti pada lingkungan tempat tinggal masyarakat setempat.

Variabel yang memiliki hubungan dengan kasus DBD di daerah endemis dan sporadis adalah kebiasaan membersihkan TPA minimal sekali dalam seminggu. Penelitian ini menunjukkan bahwa di daerah endemis dan sporadis DBD, membersihkan kontainer air dan menggunakan kelambu saat tidur dapat mencegah gigitan nyamuk 
sehingga penyakit DBD dapat dicegah. Kebiasaan dalam kehidupan sehari-hari tersebut perlu diperhatikan sebagai upaya pencegahan terhadap DBD adalah salah satu cara untuk mengendalikan kasus DBD. ${ }^{10}$

Kota Banjarbaru merupakan daerah endemis penyakit DBD karena setiap tahun selalu terjadi kasus yang tinggi. Data yang dihimpun dari Dinas Kesehatan Kota Banjarbaru didapatkan trend kenaikan angka kejadian DBD. Jumlah kasus DBD periode 2012-2016 sebanyak 557 kasus dengan tingkat endemisitas di tahun 2016 sebanyak 70\%. Pada tahun 2017 terjadi penurunan jumlah kasus DBD (56 kasus). Jumlah kasus DBD tertinggi di Kota Banjarbaru berada di Kecamatan Landasan Ulin khususnya Kelurahan Guntung Manggis sebanyak 73 kasus. Laporan tahunan dari Puskesmas Guntung Manggis, data terbaru pada bulan Januari-September 2018 terdapat kasus 20 kasus yang terkena diantaranya yang terkena DBD tersebut adalah anak-anak. ${ }^{4}$

Profil Kelurahan Guntung Manggis Merupakan kawasan pemukiman cukup padat dan merupakan perluasan wilayah yang sebelumnya hutan serta. Akses pelebaran jalan menuju kawanan perkantoran provinsi. Kondisi pemukiman yang kurang tertata dan tidak adanya drainase menyebabkan banyaknya genangan air pada saat musim hujan. ${ }^{11}$ Sementara kejadian penyakit DBD di daerah tersebut selalu mengalami peningkatan. Penelitian ini bertujuan untuk menganalisis hubungan kondisi lingkungan (suhu air, derajat keasaman $(\mathrm{pH})$, dan jenis kontainer) dengan keberadaan jentik Ae. aegypti yang merupakan vektor utama penyakit $\mathrm{DBD}$.

\section{METODE}

Penelitian ini menggunakan metode survei dengan pendekatan cross sectional. Penelitian ini dilakukan pada bulan Januari 2019. Populasi penelitian adalah semua rumah yang ada di RT 46 RW III Kota Banjarbaru sebanyak 168 rumah. Besar sampel dihitung menggunakan rumus Slovin sebanyak 63 rumah dengan menggunakan teknik random sampling. Pengumpulan jentik dilakukan dengan metode single larvae. Data karakteristik, keberadaan jentik Ae. aegypti, jenis, dan bahan kontainer diperoleh melalui pengamatan secara langsung dan dicatat dalam formulir. Data derajat keasaman $(\mathrm{pH})$ diperoleh melalui pengukuran menggunakan kertas lakmus dan suhu air menggunakan termometer air raksa.

Variabel bebas dalam penelitian ini adalah suhu air, derajat keasaman $(\mathrm{pH})$, dan jenis kontainer. Variabel terikat berupa keberadaan jentik Ae. aegypti. Analisa data untuk menganalisis hubungan antara suhu air, derajat keasaman $(\mathrm{pH})$, dan jenis kontainer dengan keberadaan jentik Ae. aegypti menggunakan uji chi-square $\left(X^{2}\right)$ dan fisher exact.

\section{HASIL}

Keberadaan jentik Ae. aegypti ditemukan di semua rumah responden berbagai kategori suhu air. Distribusi keberadaan jentik Ae. aegypti berdasarkan suhu air tersaji dalam Tabel 1.

Tabel 1. Keberadaan Jentik Aedes aegypti Berdasarkan Suhu Air dan Derajat Keasaman di RT 46 RW III Kota Banjarbaru

\begin{tabular}{|c|c|c|c|c|}
\hline \multirow[t]{2}{*}{ Variabel } & \multicolumn{2}{|c|}{ Keberadaan Jentik } & \multirow[t]{2}{*}{ Total } & \multirow[t]{2}{*}{ Persentase $(\%)$} \\
\hline & Tidak Ada & Ada & & \\
\hline Suhu Air & & & & \\
\hline 1. $27^{\circ} \mathrm{C}-30^{\circ} \mathrm{C}$ & 27 & 6 & 33 & 52 \\
\hline 2. $<27^{\circ} \mathrm{C}$ atau $>30^{\circ} \mathrm{C}$ & 1 & 29 & 30 & 48 \\
\hline \multicolumn{5}{|l|}{ Derajat Keasaman $(\mathrm{pH})$} \\
\hline 1. $6,8-7,2$ & 22 & 15 & 37 & 59 \\
\hline 2. $<6,8->7,2$ & 15 & 11 & 26 & 41 \\
\hline
\end{tabular}


Jumlah rumah yang dilakukan pengukuran kondisi lingkungan berupa suhu air sebanyak 63 rumah. Hasil penelitian menunjukkan, rerata suhu air pada kontainer adalah $27^{\circ} \mathrm{C}$ dengan suhu minimum $24^{\circ} \mathrm{C}$ dan suhu air maksimum $30^{\circ} \mathrm{C}$ (Tabel 1). Hasil uji statistik menunjukkan adanya hubungan yang bermakna antara suhu air dengan keberadaan jentik Ae. aegypti (p-value 0,000).

Berdasarkan hasil pengukuran kondisi lingkungan berupa derajat keasaman $(\mathrm{pH})$ didapatkan rerata 7,0 dengan $\mathrm{pH}$ minimal $<6,8$ dan $\mathrm{pH}$ maksimal 7,5 Pengukuran $\mathrm{pH}$ air sebagian besar rumah responden (59\%) berada pada rentang 6,8-7,2 (Tabel 1). Analisis Chisquare antara derajat keasaman $(\mathrm{pH})$ dengan keberadaan jentik Ae. aegypti menunjukan hasil bahwa tidak adanya hubungan yang bermakna antara derajat keasaman $(\mathrm{pH})$ dengan keberadaan jentik Ae.aegypti ( $p$-value $0,144)$.

Distribusi berdasarkan jenis kontainer menunjukan kontainer bak mandi lebih banyak daripada kontainer tempayan. Berdasarkan hasil pengamatan di RT 46 RW III Kota Banjarbaru ditemukan sebanyak 116 kontainer dengan jenis bak mandi (56\%) dan tempayan (44\%). Hasil uji statistik antara jenis kontainer dengan keberadaan jentik $A e$. aegypti menunjukkan hasil bahwa adanya hubungan yang bermakna (signifikan) antara jenis kontainer dengan keberadaan jentik $A e$. aegypti (p-value 0,000).

Tabel 2 Jenis dan Bahan Kontainer yang Ditemukan di RT 46 RW III Kota Banjarbaru

\begin{tabular}{ccccc}
\hline Jenis Kontainer & $\begin{array}{c}\text { Bahan } \\
\text { Kontainer }\end{array}$ & $\begin{array}{c}\text { Jumlah } \\
\text { Kontainer }\end{array}$ & $\begin{array}{c}\text { \% Kontainer } \\
\text { Diperiksa }\end{array}$ & $\begin{array}{c}\text { \% Kontainer Positif } \\
\text { Jentik }\end{array}$ \\
\hline Bak Mandi & Semen & 65 & 56 & 43 \\
Tempayan & Plastik & 51 & 44 & 57 \\
\hline Total & & 116 & 100 & 100 \\
\hline
\end{tabular}

\section{PEMBAHASAN}

Salah satu parameter lingkungan yang berhubungan nyata dengan kepadatan populasi jentik nyamuk Ae. aegypti adalah suhu air. ${ }^{12}$ Hasil penelitian menunjukkan adanya hubungan antara suhu air dengan keberadaan jentik Ae. aegypti di RT 46 RW III Kota Banjarbaru. Hasil penelitian yang sama dilaporkan di Desa Mangunjiwan Kecamatan Demak bahwa suhu air berhubungan dengan keberadaan jentik dengan $p$-value $0,024 .{ }^{12}$

Suhu air mempengaruhi siklus perkembangbiakan nyamuk pada stadium telur, jentik, dan pupa. Pada umumnya nyamuk akan meletakkan telurnya pada temperatur sekitar 20-30 ${ }^{\circ}{ }^{8}{ }^{8}$ Refleksi cahaya yang rendah dan permukaan dinding yang berpori-pori mengakibatkan suhu dalam air menjadi rendah, sehingga jenis bahan kontainer yang demikian akan disukai oleh nyamuk Ae. aegypti sebagai tempat perkembangbiakannya ${ }^{13}$.

Berdasar atas hasil pengukuran dilapangan didapatkan rerata suhu air dalam kontainer yang diperiksa adalah $27^{\circ} \mathrm{C}$ dan $\mathrm{pH}$ 7,0 . Suryaningtyas menyatakan rata-rata suhu air optimum untuk pertumbuhan nyamuk adalah $25-27^{\circ} \mathrm{C} .^{5}$

Tempat perkembangbiakan nyamuk merupakan bagian paling penting dalam siklus hidup nyamuk, karena dalam tempat perkembangbiakan ini kehidupan jentik nyamuk berlangsung dengan normal. ${ }^{14}$ Hasil penelitian menunjukkan jentik nyamuk $A e$. aegypti banyak ditemukan pada jenis kontainer bak mandi. Kondisi bak mandi yang ditemui kebanyakan tidak dicat, berwarna gelap, lembab, dan kurang ventilasi. Bak mandi berukuran besar sulit untuk diganti airnya sehingga sangat sesuai untuk 
perkembangbiakan nyamuk. Hal ini disebabkan kebiasaan masyarakat yang suka menampung air untuk kebutuhan sehari-hari di bak mandi. Masyarakat tidak menguras bak mandi secara rutin sekali seminggu sehingga tempat-tempat penampungan air tersebut berpotensi sebagai tempat perkembangbiakan nyamuk Ae. aegypti.

Penelitian lain di Kelurahan Karunrung Kota Makassar melaporkan bahwa tempat perkembangbiakan positif jentik $A e$. aegypti yaitu bak mandi, kolam ikan, sumur, kolam, ember, dan gentong plastik. Nyamuk Ae. aegypti tidak dapat berkembangbiak di genangan air yang langsung berhubungan dengan tanah. Saat nyamuk sudah siap bertelur, maka akan mencari tempat-tempat penampungan air bersih di sekitar rumah yang tidak berhubungan langsung dengan tanah, seperti bak air, kaleng bekas, dan vas bunga. ${ }^{15}$

Jenis kontainer yang digunakan responden ada hubungannya dengan keberadaan jentik nyamuk yang ditemukan di dalam kontainer tersebut, hal ini didukung hasil penelitian Sulistiyorini di Baranangsiang $(\mathrm{p}=0,06)$ dan di Bojongkerta $(\mathrm{p}=0,00)$. Di Baranangsiang dan Bojongkerta penggunaan jenis kontainer non TPA berupa tatakan dispenser yang terlihat lebih dominan dibanding yang lain. Di Baranangsiang penggunaan jenis kontainer non TPA berupa tatakan dispenser sebesar $79 \%$ yang terdapat jentik $88,88 \%$. Sedangkan di Bojongkerta sebesar $66,66 \%$ terdapat jentik. ${ }^{16}$

Bahan kontainer yang banyak ditemukan adalah dari bahan plastik. Hal ini berkaitan dengan jenis kontainer yang banyak ditemukan dalam bentuk ember plastik (tempayan). Ember merupakan jenis kontainer yang umum dan praktis digunakan oleh masyarakat karena bahan yang ringan dan mudah dibawa. Selain digunakan untuk menampung air juga dapat digunakan untuk mengangkut/memindahkan air dari satu tempat ke tempat lain.

Jenis kontainer yang didapatkan dalam penelitian lain berupa bak mandi dan drum plastik yang dominan berlumut dan berwarna gelap. ${ }^{17} \mathrm{Di}$ India juga mendapatkan bahwa jenis kontainer yang paling banyak ditemukan jentik adalah kontainer yang terbuat dari plastik sebanyak $37,84 \% .^{18}$

Tempat penampungan air berbahan dasar semen yang diperiksa umumnya berlapiskan keramik, walaupun memiliki permukaan yang tidak kasar namun pada umumnya bak memiliki permukaan dinding yang luas sehingga nyamuk senang meletakkan telurnya disana. ${ }^{19}$ Pada kontainer berbahan semen mikroorganisme yang menjadi bahan makanan jentik lebih mudah tumbuh pada dindingnya dan nyamuk betina lebih mudah mengatur posisi tubuh pada waktu meletakkan telur, dimana telur secara teratur diletakkan di atas permukaan air, dibandingkan kontainer berbahan keramik dan plastik cenderung licin. Pada kontainer berbahan licin nyamuk tidak dapat berpegangan erat dan mengatur posisi tubuhnya dengan baik sehingga telur disebarkan di permukaan air dan menyebabkan mati terendam sebelum menetas. ${ }^{20}$ Bahan kontainer dari keramik dan plastik memiliki angka positif jentik Ae. aegypti yang rendah karena bahan ini tidak mudah berlumut, mempunyai permukaan yang halus dan licin serta tidak berpori sehingga lebih mudah untuk dibersihkan dibandingkan bahan dari semen dan tanah. ${ }^{17}$

\section{KESIMPULAN}

Jenis kontainer yang ditemukan berupa bak mandi dan tempayan. Suhu air dan jenis kontainer berhubungan dengan keberadaan jentik Ae. aegypti.

\section{SARAN}

Kader dan pemegang program kesehatan di lingkungan puskesmas setempat bekerjasama dalam melakukan penyuluhan sanitasi lingkungan dan pemantauan keberadaan jentik Ae. agypti. Masyarakat juga perlu mendapatkan pengawasan terhadap keberadaan jentik Ae. agypti serta pemberdayaan pemeliharaan ikan pemakan jentik seperti ikan cupang supaya jentik tidak berkembangbiak. 


\section{UCAPAN TERIMA KASIH}

Penulis mengucapkan terimakasih kepada Universitas Islam Kalimantan MAB Banjarmasin Bagian Lembaga Penelitian selaku pemberi izin dan pemegang anggaran penelitian, Badan Pelayanan Perijinan Terpadu (BP2T) Kota Banjarbaru, dan Dinas Kesehatan Kota Banjarbaru selaku pemberi izin serta informasi data yang dibutuhkan dalam penelitian sehingga kegiatan penelitian dapat berjalan dengan baik. Penulis juga mengucapkan terimakasih kepada enumerator yang telah membantu dan berpartisipasi dalam pelaksanaan penelitian ini.

\section{DAFTAR PUSTAKA}

1. Nani. Hubungan perilaku PSN dengan keberadaan jentik Aedes aegypti di Pelabuhan Pulang Pisau. J Berk Epidemiol. 2017;5(1):112. doi:10.20473/jbe.v5i1.2017.1-12.

2. Saleh M, Aeni S, Gafur A, Basri S. Hubungan pemberantasan sarang nyamuk ( PSN ) dengan keberadaan jentik nyamuk Aedes aegypti di wilayah kerja puskesmas. J Hig. 2018;4(2):93-8.

3. Sahrir N, Ishak H, Maidin A. Pemetaan karakteristik lingkungan dan densitas nyamuk Aedes aegpti berdasarkan status endemisitas DBD di Kecamatan Kolaka. JST Kesehat. 2016;6(1):70-5.

4. Dinas Kesehatan Kota Banjarbaru. Laporan Tahunan 2018. Kota Banjarbaru;2018:1-40.

5. Suryaningtyas NH, Margarethy I, Asyati D. Karakteristik habitat dan kualitas air terhadap keberadaan jentik Aedes spp di Kelurahan Sukarami Palembang. Spirakel. 2018;9(2):539. doi:10.22435/spirakel.v8i2.8057.

6. Gafur A, Saleh M. Hubungan tempat penampungan air dengan keberadaan jentik Aedes aegypti di perumahan dinas type $\mathrm{E}$ Desa Motu Kecamatan Baras Kabupaten Mamuju Utara. J Hig. 2015;1(2):92-9.

7. Faridah L, Hamda ME, Syafei NS, Agrianfanny YN. Gambaran kontainer potensial dan kondisi lingkungannya sebagai tempat perindukan nyamuk di Universitas Padjadjaran Jatinangor. Maj Kedokt Bandung. 2018;50(2):6-9.
8. Ridha MR, Rahayu N, Rosvita NA, Setyaningtyas DE. Hubungan kondisi lingkungan dan kontainer dengan keberadaan jentik nyamuk Aedes aegpty di daerah endemis demam berdarah dangue di Kota Banjarmasin. J BUSKI. 2013;4(3):133-7.

9. Prasetyowati H, Astuti EP, Widawati M. Faktor yang berhubungan dengan keberadaan jentik Aedes aegypti di daerah endemis demam berdarah dengue ( DBD ) Jakarta Barat. BALABA. 2017;13(2):115-24.

10. Fitriana BR, Yudhastuti R. Hubungan faktor suhu dengan kasus demam berdarah dengue (DBD) di Kecamatan Sawahan Surabaya. Indones J Public Heal. 2018;13(1):83-94. doi:10.20473/ijph.vl13il.2018.83-94.

11. Kelurahan Guntung Manggis. Profil Kelurahan Guntung Manggis Kota Banjarbaru. Kota Banjarbaru;2018:1-20.

12. Maftukhah, Azam M, Azinar M. Hubungan sosiodemografi dan kondisi lingkungan dengan keberadaan jentik di Desa Mangunjiwan Kecamatan Demak. J Kesehat Masy. 2017;11(1):78-83.

13. Fauziah NF. Karakteristik sumur gali dan keberadaan jentik Aedes aegpty. J Kesehat Masy. 2012;8(1):81-7.

14. Prasetyaningsih Y, Arisandi D, Retnosetiowati PD. Persentase kejadian anemia pada petani terpapar pestisida di kelompok tani karang rejo, dusun Krinjing Lor, Desa Jatisarono, Kecamatan Nanggulan, Kabupaten Kulon Progo. The 5 Th Urecol Proceeding. Yogyakarta: UAD;2017.

15. Purnamasari AB, Kadir S, Marhtyni. Distribusi keruangan spesies larva Aedes sp. dan karakteristik tempat perkembangbiakan di Kelurahan Karunrung Kota Makasar. J Bionature. 2016;17(1):7-13.

16. Sulistyorini E, Hadi UK, Soviana S. Faktor entomologi terhadap keberadaan jentik Aedes $s p$ pada kasus DBD tertinggi dan terendah di Kota Bogor. J MKMI. 2016;12(3):137-47.

17. Alifariki LO, Mubarak. Hubungan karakteristik kontainer dengan keberadaan jentik nyamuk Aedes aegypti di wilayah kerja Puskesmas Poasia Kota Kendari. MEDULA. 2017;5(1):388-93.

18. Santoso, Taviv Y, Mayasari R, Margarethy I, Dsp IGW, Marini. Hubungan karakteristik 
kontainer dengan keberadaan jentik Aedes aegypti pada kejadian luar biasa demam berdarah dengue: Studi Kasus di Kabupaten Ogan Komering Ulu. J Vektor Penyakit. 2018;12(1):9-18.

19. Pratiwi TY, Anwar MC, Utomo B. Hubungan karakteristik tempat penampungan air dan perilaku masyarakat dengan keberadaan jentik Aedes aegypti di Kelurahan Karangklesem, Kecamatan Purwokerto Selatan Tahun 2016. J Keslingmas. 2016;37(1):56-61.
20. Aniq L. Hubungan karakteristik kontainer dengan keberadaan jentik Aedes aegpty di wilayah endemis dan non endemis demam berdarah dengue di Puskesmas Mijen tahun 2015 [Internet]. Semarang: Udinus Repository; $2015 . \quad$ Diunduh dari: http://eprints.dinus.ac.id/17465/. 
BALABA Vol. 15 No. 2, Desember 2019: 171-178 